\title{
Change in the Era of Globalization: Implications for Edu- cation and Training in Civil and Military Systems
}

\begin{abstract}
Grazia Scoppio ${ }^{1}$
Globalization is often defined in terms of the merging of economies, global markets, and border-free trading. However, globalization is not a phase or a phenomenon limited to the economic sector-it is a process that touches on many other spheres of activity. In this article, I will first define the different aspects of globalization. Regardless of one's stand towards globalization, it seems clear that it is an inevitable and unstoppable process, one which has changed the concept of nation, the make-up of societies, and which affects people's identities, lives, and work. I will then define military education and training, and provide a brief overview of some of the new challenges facing military systems internationally. In addition, I will explore the implications for the Canadian education and training systems, both civil and military. Formal and informal education, professional development, training, and retraining can be considered key factors in enabling individuals to meet the challenges of a constantly changing 'global village.'
\end{abstract}

\section{Globalization and Change}

There are several aspects to globalization. The emergence of multinational corporations, electronically connected stock markets, regional trade agreements, and economic blocs-such as the North American Free Trade Agreement (NAFTA), the European Economic Community (EEC), the Association of Southeast Asian Nations (ASEAN), and the Asia-Pacific Economic Cooperation (APEC)-have led to economic globalization through the interconnection of national economies worldwide. Technological progress, characterized by the increasing use of information technologies, computers, the Internet, robots, satellites, global networks, and faster means of transportation, has resulted in the globalization of technologies and communications. International and supranational bodies, such as the United Nations, the G8, and the European Union, have increasingly strong powers, thus creating new forms of global governance. More and more, governments' agendas are based on neoliberal theories, which oppose direct state intervention and support free markets. As a result, there have been cutbacks in social expenditures in many nations, while privatization and deregulation have increased, in order to successfully compete in world markets. This phenomenon could therefore be described as a globalization of ideologies. The facts that Western culture is often considered to be the model to which other cultures aspire, and that English is the most commonly used language in international affairs and trade—and

${ }^{1}$ Dr. Grazia Scoppio is Assistant Professor at the Canadian Defense Academy, Kingston, Ontario. 


\section{THE QUARTERLY JOURNAL}

is undoubtedly the language of computers and the Internet-are in fact forms of cultural and linguistic globalization. There is the human aspect of globalizationthat is to say, increasing movements of people, both in scale and speed. The reasons for such mobility can be work-related, travel for pleasure, and migrationboth voluntary, i.e., economic migrants, and involuntary, i.e., refugees and internally displaced persons (IDPs). Finally, "with globalization, there has also been a growing internationalisation of global conflict, crime, terrorism, and environmental issues."

Critics of globalization denounce, among other problems, the increasing gap between the technologically and economically advanced countries of the North of the world and the less developed countries of the South.

"L'économie globale provoque ainsi, paradoxalement, une cassure de la planète entre ces trois pôles [Amérique du Nord, Europe occidentale, et zone AsiePacifique] de plus en plus intégrés et le reste des pays (en particulier, l'Afrique noire) de plus en plus pauvres, marginalisés, exclus du commerce mondial et de la modernisation technologique." 3

At the same time, workers in the countries of the North are experiencing mass downsizing due to the reorganization of work, the export of jobs to cheaper labor markets, and greater automation. In this global economy, Ramonet argues, the role of the state is uncomfortable: "Il ne contrôle plus les changes, ni le flux d'argent, d'informations ou de marchandise." ${ }^{4}$ The two current global television networks, Cable News Network (CNN) and Music Television (MTV), are destined to be followed by several others in the near future. The 'masters' of this new world are people like Bill Gates, who are above such concepts as democracy, public good, and social welfare. As Ramonet notes, "À leurs yeux, le pouvoir politique n'est que le troisième pouvoir. Il y a d'abord le pouvoir économique, puis le pouvoir médiatique. Et quand on possède ces deux lá, comme Berlusconi en a fait la demonstration en Italie, s'emparer du pouvoir politique n'est plus qu'une formalité." 5

Similarly, Burbules and Torres claim that, due to neoliberal policies, "the state has withdrawn from its responsibility to administer public resources.... The neoliberal state ... is characterized by drastic cutbacks in social spending, rampant

\footnotetext{
${ }^{2}$ Nicholas C. Burbules and Carlos Alberto Torres, "Globalization and Education: An Introduction," in Globalization and Education - Critical Perspectives, ed. Burbules and Torres (New York: Routledge, 2000), 20.

${ }^{3}$ I. Ramonet, "Globalisation, Culture et Démocratie," in Mondialisation, Citoyenneté et Multiculturalism, ed. M. Elbaz and D. Helly (Saint-Nicolas, Québec: Les Presses de l'Université Laval, 2000), 33. I have purposefully kept French quotations in the original language. As noted by Bibeau, this shift from one language to the other is meant to highlight Canada's linguistic duality; see G. Bibeau, "Qui a peur des ethnies? Questions (subversives) aux politologues canadiens et québécois," in Globalization and Education.

${ }^{4}$ Ramonet, "Globalisation," 39.

${ }^{5}$ Ibid., 50.
} 
environmental destruction, regressive revisions of the tax system, loosened constraints on corporate growth, widespread attacks on organized labor, and increased spending on military infrastructure." 6

Burbules and Torres also observe that neoliberal policies have resulted in a "shrinking" public sector and a governmental emphasis on "doing more with less." The argument that the public sector is shrinking while military spending, also part of the public sector, is increasing, is not backed up with any data by the authors. In reality, after the end of the Cold War, military spending in most Western democracies has undergone continuous cutbacks. At the same time, the involvement of international military forces in peacekeeping missions has increased. This has forced military forces in many countries "to do more with less," similar to other areas of the public sector. As a result of sustained cuts to the U.S. defense budget in past years, reductions and downsizing have affected military manpower and the status of worldwide bases as well as military education. Thus, American forces have also been struggling to do more with less. ${ }^{8}$ Similarly, government agencies and institutions in Canada, including the Canadian armed forces, have been subject to financial cuts and personnel reductions: "not surprisingly, much more had to be done with considerably less...." More recently, the situation in many Western countries has changed somewhat. After the tragic events of September 11, 2001, the possibility of further attacks on the U.S. and other Western countries has come to be seen as a very real threat. Consequently, the public, the media, and governments are paying renewed attention to the importance of maintaining efficient and modern national defense systems. However, according to Burbules and Torres, political institutions are not adequately addressing global issues related to conflict, crime, terrorism, and the environment. ${ }^{10}$ The fact is that all public services, personnel, and infrastructures are vital to the very existence of a country, and they should be not only maintained but also continuously renewed.

Although some of the arguments proposed by anti-globalization writers, academics, and movements may have some merit, not all the evils of the worldfrom unemployment to poverty, and from illiteracy to xenophobia—can be attributed to the globalization process. In our imperfect world, social problems have always existed and will unfortunately not cease to exist, because no system has so far been able to achieve the perfect social balance. Having said that, I am not advo-

\footnotetext{
${ }^{6}$ Burbules and Torres, "Globalization and Education," 8.

${ }^{7}$ Ibid., 20.

${ }^{8}$ Bill Taylor, ed., Professional Military Education: An Asset for Peace and Progress, CSIS Study Group on Professional Military Education, Dick Cheney (Chair) (Washington, D.C.: The Center for Strategic and International Studies, 1997), 2.

${ }^{9}$ C. Lemieux, "Articulating the Vision of the Canadian Officer Corps of 2020: Understanding the Leadership and Ethical Challenges," Canadian Military Journal (Spring 2000): 32.

${ }^{10}$ Burbules and Torres, "Globalization and Education," 20.
} 


\section{THE QUARTERLY JOURNAL}

cating a passive acceptance of whatever inequities may result from globalization, but rather a more objective perspective. Criticism, whether in theoretical form or in its more practical manifestations, should be constructive, not destructive. Statements such as, "le devenir du monde du capitalisme ne scelle aucun avenir. Loin s'en faut. En m'abritant derrière le poète René Char, je dirais que notre heritage est sans testament," leave no hope for the future. ${ }^{11}$

A more positive outlook is needed. Our heritage and values will live on, as long as we pass them on to our children and youth. Heritage, in modern terms, is often characterized as simply being made up of multiple cultural influences, including ethnicity, language, religion, and nationality/citizenship; but the values that inform our heritage should include the fundamental principles of equity, justice, and human rights. Violent upheavals, such as those witnessed in Quebec City and Genoa during recent outbursts of anti-globalization protest, have caused chaos and fear. Individuals, non-governmental organizations, and antiglobal movements should express their views through the democratic tools at their disposal, such as voting, advocacy, grass-roots movements, and peaceful meetings or expressions of public opinion.

Furthermore, not everything resulting from globalization is negative. The Internet, considered "one of the chief manifestations of globalization and one of its primary causes," is not only a tool used for economic/corporate ends. ${ }^{12}$ It enables people worldwide to communicate instantaneously, to interact with culturally diverse societies, to teach and learn on-line, and to retrieve all kinds of information, including data, reports, and electronic journals that help to inform researchers, academics, and policy-makers in addition to private citizens in general. Burbules considers the Internet to be a learning community that functions in a heterogeneous manner, with participants from different affiliations and with different learning styles. He believes that on-line communities "will become of even greater importance to the educational opportunities of learners of all ages, across all parts of the world." 13

Notwithstanding its merits and shortcomings, globalization is undoubtedly an inevitable and unstoppable historical process, just like any other large-scale historical tendency, such as industrialization. As borders become more porous within regional trading areas, and as intra-national and supranational forms of governance become stronger, the whole concept of the nation-state, formerly seen as a closed, self-governing unit, has changed. The make-up of societies has also changed, due to increasing ethnic, cultural, linguistic, and religious diversity. As people travel more, acquire dual or multiple citizenship, speak more than one language, and are

\footnotetext{
${ }^{11}$ M. Elbaz, "L'inestimable lien civique dans la societé -monde," in Mondialisation, Citoyenneté et Multiculturalisme, 25.

${ }^{12}$ Nicholas C. Burbules, "Does the Internet Constitute a Global Educational Community?" in Globalization and Education, 349.

${ }^{13}$ Ibid., 352.
} 
exposed to an overload of information, their identities have become multiple. In modern societies, changes occur so rapidly that individuals cannot live in a static way, as if living in a vacuum. Changes brought about by globalization influence people's lives and work, and thus the way they approach life and prepare for the job market must also change. A globalized world calls for people who are dynamic, analytical, flexible, technologically literate, and open to diversity, foreign cultures, and new ideas. The global citizen cannot live 'stuck in time,' but must be able to accept and adapt to change. Education and training are fundamental resources in providing individuals with the knowledge and skills necessary to function in a constantly changing environment, both in civil society and in military contexts.

\section{Military and Civil Education and Training}

Military education and training are at times defined as two ends of a spectrum, and at other times as having overlapping elements. Anderson sees the learning process as a "spectrum, with 'pure training' (such as a simple exercise of assembling a rifle) at one end, with 'pure education' (involving the highest level of abstraction) at the other." ${ }^{14}$ Lawson defines military training as a process that "includes not only the learning or acquisition of initial skills, knowledge and understanding necessary for the performance of tasks and roles, but also frequent rehearsal and practice.... Training therefore involves frequent retraining...." ${ }^{15}$ He further explains that, although there is some overlap between training and education, training is sometimes considered a narrow form of learning, whereby skills are learned for a specific purpose, which is morally neutral. Conversely, he defines education as a broader form of learning, which is knowledge-based, "has values built into it and is often regarded as a worthwhile end apart from any extrinsic purposes which it might serve." The problem, according to Lawson, "seems to be in combining the open-ended forms of thinking inherent in the educational approach, with the narrower goals of training." 16

For Haycock, training and education are different concepts:

[T]raining is a predictable response to a predictable situation. Education on the other hand, is a 'reasoned' response to an unpredictable situation-that is, critical thinking in the face of the unknown. Modern soldiering demands that both

\footnotetext{
${ }^{14}$ C. L. Anderson, "Educating the United States Army," in The Educating of Armies, ed. Michael D. Stephens (London: The Macmillan Press Ltd., 1989), 40.

${ }^{15}$ K. Lawson, "The Concepts of 'Training' and 'Education' in a Military Context," in The Educating of Armies, 2.

${ }^{16}$ Ibid., 7, 11.
} 
education and training reside together and are absolutely necessary. But they are fundamentally different. ${ }^{17}$

He also writes that there has not been enough emphasis on military education, as the focus has traditionally been on military training: "By definition, soldiers do a whole lot of the latter, but not necessarily as much of the former." 18

Through this brief overview of the literature, we can see that military education and military training are defined as having different learning objectives, although at times they have some overlapping elements. Overall, the military as well as the general system of education and training bear many similarities. Although the skills and concepts to be learned may be different in general education and training than in the military system, the teaching approaches and learning processes are similar. Thus, we can define both general and military training as the teaching of skills that enable the learner to perform a specific job or task. In the same way, general and military education can both be defined as the teaching of different subject matters, mainly aiming at the acquisition of knowledge. It follows that, in our knowledge-based society, greater emphasis is being placed on acquiring a 'good education.' Similarly, the problem identified in different military systems is the need to complement military training with more educational opportunities.

\section{Some Issues Concerning International Military Education and Training}

Research carried out in different countries has uncovered some of the challenges existing in military education and training. Consequently, recommendations have been made for improving existing programs and for future planning. New systems of sophisticated military hardware require soldiers who "must demonstrate the capacity to be flexible and resourceful.... Soldiers must be both technically and tactically competent." ${ }^{19}$ Education must focus not only on reading, written and oral communication, and mathematics, but also on "computer literacy, information management and abilities to think, reason and problem solving under stress." 20 These objectives may be harder to achieve for new immigrants or people of low socio-economic status; as Anderson discusses in the case of the U.S., some minority soldiers, mainly from Hispanic or African-American backgrounds, lack proficiency in English or have achieved only marginal literacy.

The American report entitled Professional Military Education: An Asset for Peace and Progress attempts to find the answer to two main questions. First,

\footnotetext{
${ }^{17}$ R. G. Haycock, "The Labours of Athena and the Muses: Historical and Contemporary Aspects of Canadian Military Education,"Canadian Military Journal (Summer 2001): 8.

${ }^{18}$ Ibid., 8.

${ }^{19}$ Anderson, "Educating the United States Army," 62.

${ }^{20}$ Ibid., 63.
} 
what are the challenges confronting military forces today? Second, what are the unique demands of the military profession? Some of the changes in the nature and scope of modern military operations include an increase in "operations 'other than war' - peacekeeping, peacemaking, humanitarian assistance, and disaster relief." In addition, new information technologies have brought about "changes in the technology of warfare." Finally, "service members are confronting increasingly complex ethical dilemmas for which they are inadequately prepared" 21 The CSIS panel made several recommendations, including the suggestion that the Reserve Officer Training Corps (ROTC) should strive to maintain the existing socioeconomic, racial, and geographic diversity of their pool of future officers, as a reflection of the diversity in the American population. The panel also suggested that all service academies should adopt Leadership Development Programs and Consideration of Others Programs, similar to those introduced at the U.S. Military Academy at West Point. As officers face new responsibilities and ethical dilemmas, ethics instruction programs should be mandatory in professional military education. New military technology and the changing nature of military operations require officers to be able to "exploit advanced technologies" and at the same time to possess new knowledge and skills "in the realm of foreign languages, history, world affairs, and conflict resolution, as well as in military art and joint coalition operations." 22 The panel suggested that curricula should be adjusted to reflect these new needs, including placing more emphasis on peacemaking and peacekeeping.

Similarly, in the case of the British Army, Ryan has identified a need for better-educated officers and soldiers. Cost-effective and efficient training will be even more important in order to ensure that the best use is made of scarce human and material resources. Unlike many civilian organizations, the Army cannot simply import or recruit ready-made leaders as senior officers and NCOs as they are needed. It has to cultivate its own; the young men and women who are recruited in their late teens or early twenties provide the military leaders of the future. Consequently, there has to be a progressive educational and training process to prepare officers and soldiers to fill positions of increasing responsibility as their careers develop. ${ }^{23}$

For the Israel Defense Force (IDF), the main task has been to solve "Israel's harsh security problems whilst integrating a heterogeneous population." ${ }^{24}$ To do so, the educational goals of the IDF have included improving the soldiers' knowledge of Hebrew, deepening their sense of belonging within the military, and helping them broaden their education.

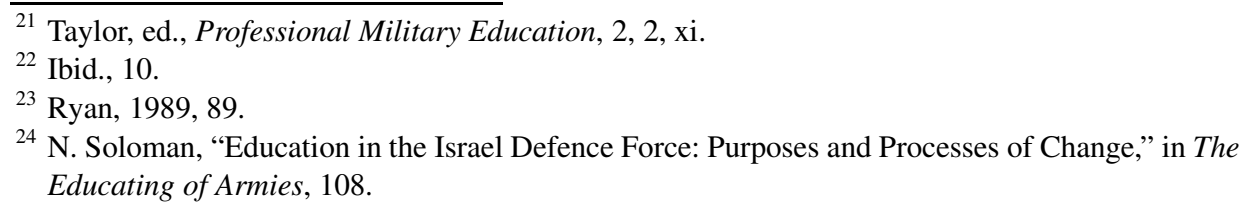




\section{THE QUARTERLY JOURNAL}

In Canada, according to the recently released report, Canadian Officership in the $2{ }^{\text {st }}$ Century or Officership 2020, there is a need for a strong educational component in the professional development of officers in order to meet the complex challenges of military operations, which require officers to be able to think critically and to use technology. ${ }^{25}$ Officership 2020 included a research project called "Debrief the Leaders," which involved gathering the experiences and views of over 800 officers. The focus groups, survey questionnaires, and interviews that made up the study addressed a wide range of issues, including "training, leadership, coping with the media, dealing with cultures, decision-making and communications." ${ }^{26}$ Some of the problems uncovered include difficulties in dealing with ethical dilemmas and with cultural and structural differences. Furthermore, the multinational peacekeeping or conflict-resolution operations in which Canadian forces are increasingly deployed require officers to operate in contexts where they need to understand and interact and cooperate with the many actors involved, namely nation-states, international organizations, non-governmental organizations, and international media. In this changing context, the former concept of the "soldier as a warrior" must be complemented by the new image of "the soldier as a diplomat and scholar." 27

From this brief overview, we can see that there are some similar problems facing military forces internationally. In this globalized environment, the new abilities and skills required of soldiers and officers are not dissimilar to those required of civilians who are competing in a fast-changing, highly technological, and highly diverse job market. The common question then is, What is the role of education and training in preparing these new global citizens, both civilian and military, for the challenges of globalization?

\section{Implications for Education and Training in Canada}

In the era of globalization, life-long learning and workplace change have become keywords everywhere, including Canada. It is no longer possible to acquire everlasting skills and knowledge. Education and training should be continuously updated and upgraded. The acquisition of diverse skills and abilities makes it possible for individuals to adapt to change. Thus learning cannot be regarded as a static concept but as a dynamic and continuous process whereby formal and informal education, training, re-training, and professional development all complement each other.

In general terms, Canadians in civil society, both citizens and newcomers, are better educated than in the past. In addition, data compiled by Statistics Canada

\footnotetext{
${ }^{25}$ Canadian Officership in the $21^{\text {st }}$ Century (Officership 2020). Strategic Guidance for the Canadian Forces Officers Corps and the Officer Professional Development System (Ottawa: Department of National Defense, 2001).

${ }^{26}$ Lemieux, "Articulating the Vision," 33.

${ }^{27}$ Ibid., 36.
} 
show that there is greater participation of women and so-called 'visible minorities' in post-secondary programs at the university level and in community colleges. However, recent research reports have shown that Canadian officers are not educated enough. ${ }^{28}$ The new reforms contemplated for the Canadian Forces' system of education and training, including the creation of the Canadian Defence Academy (CDA), are definitely aimed at filling this gap. ${ }^{29}$

Post-secondary education programs should increasingly focus on enabling learners to develop the ability to think critically, communicate clearly, write effectively, analyze objectively, and research efficiently. The kind of education needed to stimulate individuals' cognitive activities and help them develop high levels of intellectual ability is a liberal arts education with a multidisciplinary approach. That is to say, one that focuses not only on traditional and technical subjects, which are essential in many professions and lie at the heart of military education, but also encompasses a wider range of subjects from fields in the humanities and social sciences. The curriculum would embrace, for example, migration and refugee studies, international studies, multicultural and citizenship programs, global education courses, peace education courses, and courses dealing with the relationship between the individual and society. Faculty personnel and students should be from diverse backgrounds, in order to reflect the cultural and ethnic diversity of the Canadian population and to provide a wide range of teaching and learning approaches. For example, following Dewey's theory that we learn through experience, an experiential approach to learning would enable students to share their own experiences as well as listen to and learn from the experiences of others. $^{30}$

Teaching methodologies should take into account that adults learn differently from children. Students in academic programs should assume more responsibility, and be given greater choice in what they learn and how they learn it. This can be achieved by incorporating new methods into the traditional forms of teaching, such as lecturing, term papers, and formal presentations. These new methodologies could include on-line learning and different peer-learning opportunities, such as group work, exchanges of ideas led by student discussants, group research assignments, peer evaluations, or open-book examinations. They should also involve increased use of computers, audio-visual equipment, field trips, and guest speakers - that is, experts and practitioners from academia, the military, international organizations, NGOs, the corporate sector, and so on. Similarly, training should aim not only at learning what to do in war situations, but also what to do in

\footnotetext{
${ }^{28}$ Haycock, "Labours of Athena," 9.

${ }^{29}$ See "A Charter for the Canadian Defence Academy," at http://kingston.mil.ca/cda (17 July 2002); and A. C. Eggleton, "Message from the Minister of National Defence," Maple Leaf 4:17 (May 9, 2001), at www.dnd.ca/menu/maple/vol_4/vol4_17/dnews2_e.htm (21 July 2002).

${ }^{30}$ John Dewey, Experience and Education (New York: Macmillan, 1963).
} 
peacekeeping environments, through such exercises as conflictresolution training and cultural awareness training.

\section{Conclusion}

In this fast-changing, globalized environment, education and training, whether civilian or military, should be viewed as an integrated, dynamic, and continuous process. Through this process, individuals will be better able to adapt to change in their lives, in the environment, in the workplace, and in modern society in general. It is now more important than ever for governments to reform their education and training systems to meet the challenges of globalization. Ongoing research should be carried out to inform policy-makers about problems in implementation, the shortcomings of the system, potential solutions to pursue, and the results obtained through reforms.

Globalization should not be regarded as implying the end of the nation-state and the end of the public system, as suggested by Green: "Indeed the whole logic of postmodern and globalization theory is that the national educational system per se is now defunct.... As the national state becomes a marginal force in the new world order ... national education ceases to exist." ${ }^{31}$ Former concepts of the nation-state and social welfare systems have evolved due to the influences of globalization, as previously described, but they have not ceased to exist, nor will they anytime soon. Should public systems and institutions no longer exist, that would be a threat to the very notion of democracy.

${ }^{31}$ A. Green, Education, Globalization and the Nation State (1997), quoted in R. A. Morrow and Carlos A. Torres, "The State, Globalization, and Educational Policy," in Globalization and Education, 36 . 


\section{Bibliography}

Anderson, C. L. "Educating the United States Army." In The Educating of Armies, 40. London: The Macmillan Press Ltd, 1989.

Burbules, Nicholas C., and Carlos Alberto Torres. "Globalization and Education: An Introduction." In Globalization and Education - Critical Perspectives, 20. New York: Routledge, 2000.

Canadian Ofcership in the 21 Century (Ofcership 2020). Strategic Guidance for the Canadian Forces Ofcers Corps and the Ofcer Professional Development System. Ottawa: Department of National Defense, 2001.

Dewey, John. Experience and Education. New York: Macmillan, 1963.

Eggleton, A. C. "Message from the Minister of National Defence." Maple Leaf 4, no. 17 (2001).

Green, A. Education, Globalization and the Nation State., 1997.

Haycock, R. G. "The Labours of Athena and the Muses: Historical and Contemporary Aspects of Canadian Military Education." Canadian Military Journal (2001): 8 .

Lawson, K. "The Concepts of 'Training' and 'Education." In Military Context, in The Educating of Armies, 2. London: The Macmillan Press Ltd., 1989.

Lemieux, C. "Articulating the Vision of the Canadian Of cer Corps of 2020: Understanding the Leadership and Ethical Challenges." Canadian Military Journal (2000): 32 .

Ramonet, I.. "Globalisation, Culture et Démocratie." In Mondialisation, Citoyenneté et Multiculturalism, 33. Saint-Nicolas, Québec: Les Presses de l'Université Laval, 2000.

Soloman, N. "Education in the Israel Defence Force: Purposes and Processes of Change." In The Educating of Armies, 108. London: The Macmillan Press Ltd., 1989.

Taylor, Bill. Professional Military Education: An Asset for Peace and Progress In CSIS Study Group on Professional Military Education, Dick Cheney (Chair). Washington, D.C.: The Center for Strategic and International Studies, 1997. 